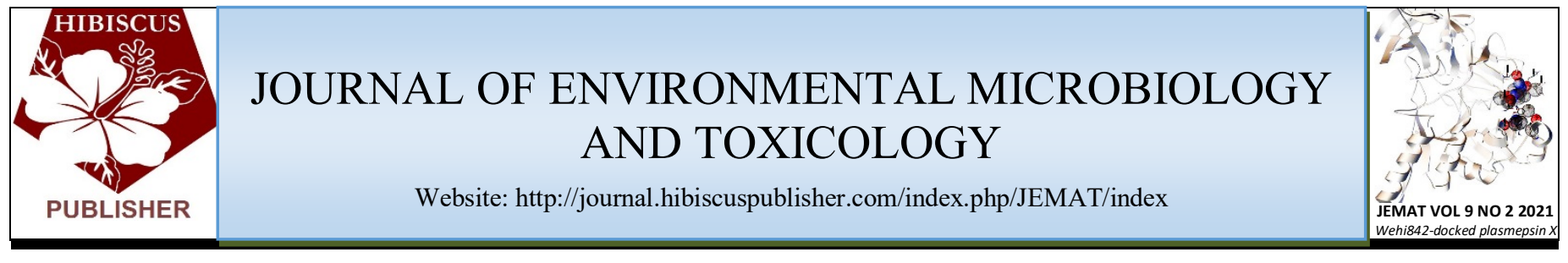

\title{
Characterization of Butachlor Degradation by A Molybdenum- Reducing and Aniline-degrading Pseudomonas sp.
}

\author{
Sufyan, A.J. ${ }^{1}$, Ibrahim, S. ${ }^{1,2}$, Babandi, A. ${ }^{1}$ and H.M. Yakasai ${ }^{1 *}$ \\ ${ }^{1}$ Department of Biochemistry, Faculty of Basic Medical Sciences, College of Health Science, \\ Bayero University, Kano, P. M. B 3011, Nigeria. \\ ${ }^{2}$ Centre for Biotechnology Research, Bayero University Kano P. M. B 3011, Nigeria.
}

*Corresponding author:

Tel: +2348034966925

Email: hmyakasai.bch@buk.edu.ng

\section{HISTORY \\ Received: $15^{\text {th }}$ Oct 2021 \\ Received in revised form: $24^{\text {th }}$ Nov 2021 Accepted: $6^{\text {th }}$ Dec 2021}

\section{KEYWORDS}

Bioremediation

Butachlor-degrading

Aniline-degrading

Molybdenum-reducing

Pseudomonas sp.

\begin{abstract}
Butachlor is a chloroacetanilide herbicide that is selective in action and commonly used for preemergence control of weeds. It is believed to have range of toxicity from acute to chronic and also can cause DNA strand breaks and chromosomal aberrations in humans. This study was aimed at characterizing the potential of previously isolated bacteria for butachlor degradation. The isolates from culture collection, labelled A-F were screened for butachlor degradation on Bushnell Hass agar media with butachlor as a sole carbon source. Isolate A (molybdenumreducing and aniline-degrading Pseudomonas sp.) was observed to grow best and tolerated the highest concentration of butachlor supplemented in the media after $72 \mathrm{~h}$ of incubation at $37^{\circ} \mathrm{C}$. Characterization study revealed that the Pseudomonas sp. can utilize and grow with butachlor at optimum $\mathrm{pH}$ between $6.0-6.5$, temperature between $30-37^{\circ} \mathrm{C}$ and can tolerate up to $600 \mathrm{mg} / \mathrm{L}$ butachlor concentration with increase in growth as inoculum size increases. Additionally, this bacterial strain shows no lag phase regardless of the concentration of the herbicide used and reach its maximum growth after $24 \mathrm{~h}$ of incubation. The ability of this isolate to tolerate and utilize butachlor as sole carbon source makes it suitable for future bioremediation of this toxicant.
\end{abstract}

\section{INTRODUCTION}

Herbicides are chemicals predominantly used in agricultural systems to control weeds. Although there exist other substances that can be used to achieve same result, herbicides are made solely for this purpose [1]. Butachlor (N'-(butoxymethyl)-2chloro-2',6'-diethyl acetanilide) belongs to the chloroacetanilide compound of carbamate group which is selective in action and is widely used by farmers [2]. It is used in the pre-emergent control of weeds [3]. Butachlor can cause DNA strand breaks and chromosomal aberrations [4], it is cytotoxic and can cause apoptosis in humans [5], and can also cause dissipation of mitochondrial membrane potential [6]. It was reported to be toxic to certain aquatic lives [7]. In soil, butachlor is toxic to earthworms $[8,9]$, while also inhibiting production and oxidation of methane in flooded tropical soils [10].

Looking at the vast number of threats that butachlor poses to the environment, finding a way to tackle these become necessary. This led to the exploration of various processes that can be applied to safely control this pollution in an eco-friendly manner. Nevertheless, biochemical and physical factors in the environment does affect the fate of these organic pollutants [11].

Bioremediation as a technique is a biological mechanism of recycling waste into form that can be used by microorganisms
[12]. However, microorganisms dwelling in these polluted environment are the key to the method of bioremediation/ biodegradation [13]. Similarly, suitable physical factors like $\mathrm{pH}$ and temperature enhances their degrading ability [14]. In comparison to other methods of remediation, the low-cost feature of bioremediation made it the most adopted and suitable method for remediation. So far, bioremediation has been defined differently by different scholars, nevertheless, all the definitions emphasized on one process, degradation [15].

Perhaps, characterization works on butachlor-degrading isolates are grossly inadequate considering the utilization and toxicity caused by this herbicide. Thus, necessitate the need to isolate and characterize more microbes with potential to degrade this environmental contaminant. This work will therefore, screened previously isolated bacteria for their potential to degrade and utilized butachlor as sole carbon source. 


\section{MATERIALS AND METHODS}

\section{Chemicals and equipment}

Butachlor of high purity was procured from distributors in Sabon Gari market in Kano. Bushnell Hass media $(\mathrm{g} / \mathrm{L})$ containing $\mathrm{CaCl}_{2}, 0.02 ; \mathrm{FeCl}_{3}, 0.05 ; \mathrm{MgSO}_{4}, 0.2 ; \mathrm{KH}_{2} \mathrm{PO}_{4}, 1.0 ; \mathrm{K}_{2} \mathrm{HPO}_{4}, 1.0$; $\mathrm{NH}_{4} \mathrm{NO}_{3}, 1.0 \mathrm{~g} / \mathrm{L}$ was prepared in distilled water. Nutrient broth was used for growth of bacterial culture. All the chemicals used in this study were of analytical grade.

\section{Media and Media Preparation}

\section{Nutrient Agar}

In a $250 \mathrm{ml}$ conical flask, $3.4 \mathrm{~g}$ of nutrient agar was added to 120 $\mathrm{ml}$ of distilled water and autoclaved at $121{ }^{\circ} \mathrm{C}$ for 45 minutes. The medium was used to determine the viability of isolates.

\section{Mineral salt medium}

Media broth was prepared by adding $(\mathrm{g} / \mathrm{L}) ; \mathrm{KH}_{2} \mathrm{PO}_{4}, \mathrm{~K}_{2} \mathrm{HPO}_{4}$, $\mathrm{MgSO}_{4}, \mathrm{CaCl}_{2}, \mathrm{FeCl}_{3}, \mathrm{NH}_{4} \mathrm{NO}_{3}$ to $400 \mathrm{ml}$ of distilled water in a $1000 \mathrm{ml}$ beaker. Measured volume of the medium was then taken and transferred each into conical flasks, the flask containing the medium were then autoclaved at $121{ }^{\circ} \mathrm{C}$ for 45 minutes. 100 $\mathrm{mg} / \mathrm{L}$ (unless otherwise stated) concentration of butachlor was used for degradation study. Agar $(20 \mathrm{~g} / \mathrm{L})$ was added to solidify the media. $120 \mathrm{ml}$ of solid medium was used in screening the six (6) isolates for butachlor degradation.

\section{Screening for Butachlor-Degrading Isolates}

Screening of isolates was carried out in petri dish. In each plate, $20 \mathrm{ml}$ of prepared solid media was added under a lamina flow and allowed to solidify. To all the petri dish, bacterial isolates labelled (A-F) were inoculated and incubated for $72 \mathrm{~h}$. Screening for maximum growth was done macroscopically.

\section{Characterization of Butachlor-Degradation}

Optimum condition for butachlor-degradation was determined using a method from [16] with some modifications. Liquid mineral salt media was used at a temperature of $37^{\circ} \mathrm{C}$, butachlor concentration of $100 \mathrm{mg} / \mathrm{L}$ and inoculum size of $100 \mu \mathrm{L}$ unless otherwise mentioned. Each of the test was conducted in triplicates.

\section{Effect of Incubation Time}

The effect of incubation time was tested by inoculating Pseudomonas sp. into the liquid media in a $250 \mathrm{ml}$ flask and incubated for $120 \mathrm{~h}$. Optical density was measured at $24 \mathrm{~h}$ intervals using a spectrophotometer at a wavelength of $600 \mathrm{~nm}$ to observe the growth rate of the isolate. Control bottles were prepared without the inoculum and kept under the same condition as the inoculated test bottles.

\section{Effect of Butachlor Concentration}

The effect of butachlor concentration in the media was studied by adding Pseudomonas sp. inoculum of $100 \mu \mathrm{L}$ volume into the liquid media containing different butachlor concentrations $(50$, $100,200,400,600$ and $800 \mathrm{mg} / \mathrm{L}$ ) were used, tests were conducted in triplicates. Optical densities were measured at $24 \mathrm{~h}$ intervals using a spectrophotometer at a wavelength of $600 \mathrm{~nm}$ to observe the growth rate of the isolate. Control bottles were prepared without the inoculum and kept under the same condition as the inoculated test bottles.

\section{Effect of $\mathbf{p H}$}

The effect of $\mathrm{pH}$ in the media was tested by putting Pseudomonas sp. inoculum of $100 \mu \mathrm{L}$ volume into the liquid media of varying $\mathrm{pH}(5.5,6.0,6.5,7.0,7.5$ and 8.0) in a $250 \mathrm{ml}$ bottles each and incubated. The $\mathrm{pH}$ was adjusted using $\mathrm{NaOH}$ and $\mathrm{HCl}$ prior to the sterilization. Optical densities were measured at $24 \mathrm{~h}$ intervals using a spectrophotometer at a wavelength of $600 \mathrm{~nm}$ to observe the growth rate of the isolate. Control bottles were prepared without the inoculum and kept under the same condition as the inoculated test bottles.

\section{Effect of Inoculum Size}

The effect of inoculum size was tested by inoculating different volumes $(50,100,200,400,600,800$ and $1000 \mu \mathrm{L})$ of Pseudomonas sp. into the liquid media in $250 \mathrm{ml}$ bottles and incubated for $120 \mathrm{~h}$. Optical densities were measured at $24 \mathrm{~h}$ intervals using a spectrophotometer at a wavelength of $600 \mathrm{~nm}$ to observe the growth rate of the isolate. Control bottles were prepared without the inoculum and kept under the same condition as the inoculated test bottles.

\section{Effect of Temperature}

The effect of temperature was tested by inoculating Pseudomonas sp. into $100 \mathrm{ml}$ of the liquid media in a $250 \mathrm{ml}$ bottles and incubated for $120 \mathrm{~h}$ at different temperatures $(25,30$, 37 and $40{ }^{\circ} \mathrm{C}$ ). Optical density was measured at $24 \mathrm{~h}$ intervals using a spectrophotometer at a wavelength of $600 \mathrm{~nm}$ to observe the growth rate of the isolate. Control bottles were prepared without the inoculum and kept under the same condition as the inoculated test flasks.

\section{RESULTS AND DISCUSSION}

\section{Screening for Butachlor-Biodegrading Isolates}

A total of six (6) previously isolated molybdenum-reducing bacteria obtained from Agricultural soils in Kano state were screened for their potential to degrade butachlor and utilize it as sole source of carbon. Out of which isolate A (Pseudomonas sp.) was observed to tolerate and grow best on Bushnell Hass media containing butachlor as sole carbon source following $72 \mathrm{~h}$ of incubation at $37^{\circ} \mathrm{C}$, thus was chosen for further analysis.

\section{Characterization of Butachlor-Degradation by Pseudomonas sp.}

\section{Effect of Incubation Time}

The result of effect of incubation time shows that Pseudomonas sp. grows exponentially from 0 to $24 \mathrm{~h}$ attaining optimum at 24 $\mathrm{h}$, after which a significant $(\mathrm{p}<0.05)$ was observed (Fig. 1).



Fig. 1. Effect of incubation time on butachlor degradation by Pseudomonas sp. Data represent mean \pm standard deviation of the triplicates 


\section{Effect of concentration}

The effect of various concentrations of butachlor on its degradation was assessed between $50-800 \mathrm{mg} / \mathrm{L}$. It was found that a concentration of $600 \mathrm{mg} / \mathrm{L}$ to be optimum for Pseudomonas sp. with a sharp decline in growth on increasing concentration to $800 \mathrm{mg} / \mathrm{L}$ (Fig. 2).

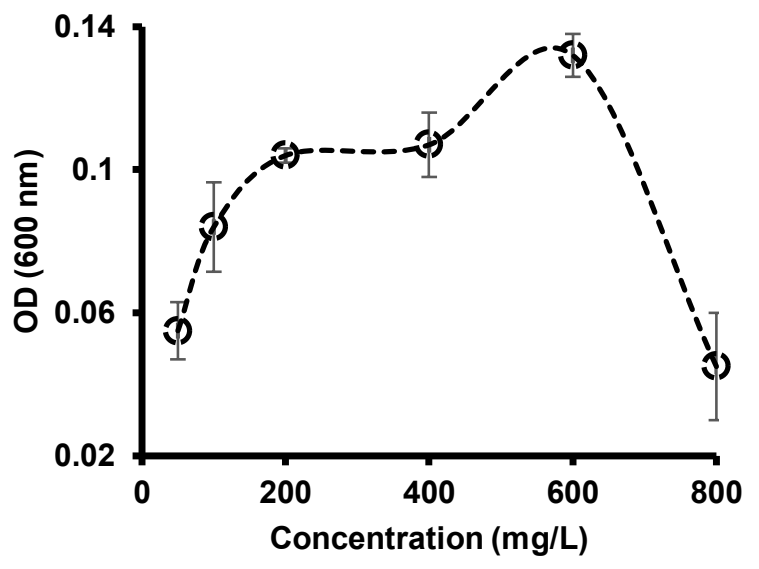

Fig. 2: Effect of various concentrations of butachlor (carbon source) on its degradation by Pseudomonas sp. after $24 \mathrm{~h}$ incubation at $37^{\circ} \mathrm{C}$. Data represent mean \pm standard deviation of triplicate measurements.

\section{Effect of inoculum size}

An inoculum volume between $100-1000 \mu \mathrm{L}$ was used to determine the effect of inoculum size. It was found that the growth of this bacteria increases almost linearly with insignificant ( $p>0.05$ ) variation between 200 to $400 \mu \mathrm{l}$ (Fig. 3).

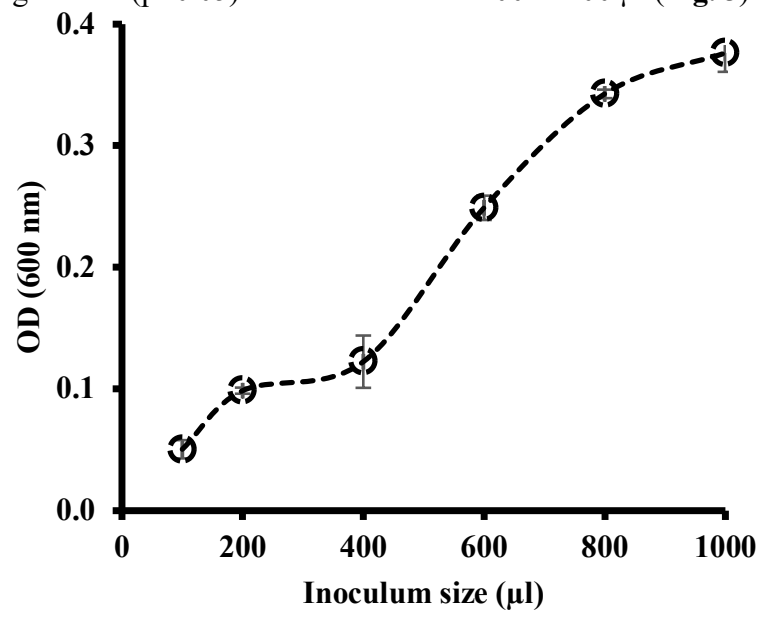

Fig. 3. Effect of inoculum sizes on butachlor-degradation by Pseudomonas sp. after $24 \mathrm{~h}$ incubation at $37^{\circ} \mathrm{C}$. Data represent mean \pm standard deviation of triplicate measurements.

\section{Effect of initial $\mathrm{pH}$}

The effect of $\mathrm{pH}$ on butachlor-degradation by Pseudomonas sp. was determined over a $\mathrm{pH}$ range of 5.5 - 8.0. The result obtained showed that the growth was optimum at $\mathrm{pH}$ between 6.0 and 6.5 with the latter having slightly higher support which was insignificant $(\mathrm{p}>0.05)$. Although, the growth decreases as the $\mathrm{pH}$ increased from 6.5 to 8.0 over $24 \mathrm{~h}$ incubation, there was an insignificant $(\mathrm{p}>0.05)$ difference in growth at $\mathrm{pH}$ between 7.0 and 7.5 (Fig. 4).

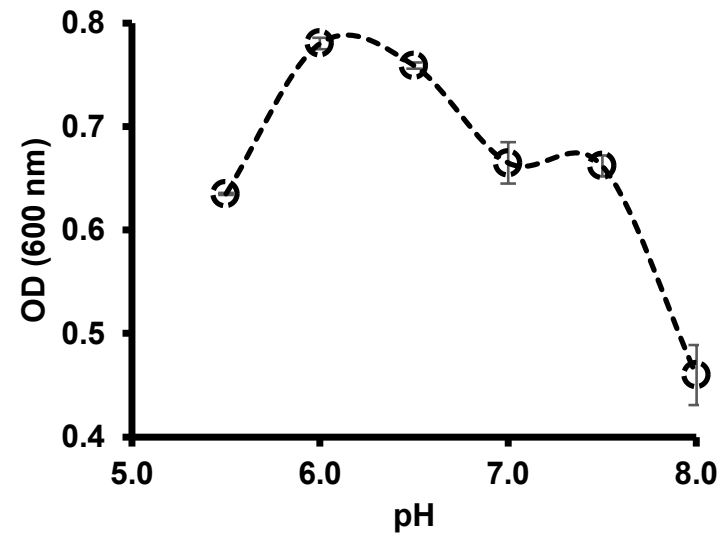

Fig. 4. Effect of various initial $\mathrm{pH}$ on butachlor-degradation by Pseudomonas sp. after $24 \mathrm{~h}$ incubation. Data represent mean \pm standard deviation of triplicate measurements.

\section{Effect of Temperature}

The effect of temperature on the growth and butachlor-degrading potentials of Pseudomonas sp. was tested within a temperature range of $25-45^{\circ} \mathrm{C}$. The result obtained showed that the growth of this bacterium was optimum at temperature between 30 and 37 ${ }^{\circ} \mathrm{C}$ with insignificant difference $(\mathrm{p}>0.05)$ between this temperature range. Additionally, growth of this bacterium was lowest at 25 and $45^{\circ} \mathrm{C}$ after $24 \mathrm{~h}$ incubation (Fig. 5).

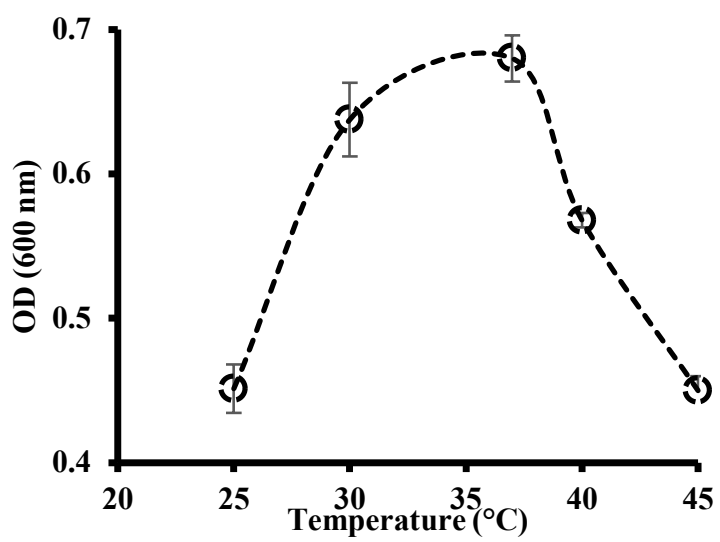

Fig. 5. Effect of temperatures on butachlor degradation by Pseudomonas sp. after $24 \mathrm{~h}$ incubation. Data represent mean \pm standard deviation of triplicate measurements.

\section{DISCUSSION}

The present study showed that the bacteria quickly adapt in the media showing a very small lag phase (or none at all), growing exponentially for up to $24 \mathrm{~h}$ where the maximum growth was observed in all cases. Growth declined after $24 \mathrm{~h}$ due to exhaustion of carbon source (butachlor) and accumulation of toxic substances. Another study of Pseudomonas sp. potential to degrade butachlor showed that the bacteria can grow in liquid salt media containing the herbicide no matter the concentration of the chemical added to the media, hence considered effective for remediation of this chemical [17]. Additionally, in another study of butachlor degradation where Mycobacterium sp. J7A and Sphingobium sp. J7B isolated from rice paddy soil were used to biodegrade butachlor in a syntrophic process, they were capable of degrading this pollutant completely in $24 \mathrm{~h}$ [3]. 
Test set to determine the tolerance of this bacterium to the effect of the chemical showed a remarkable resistance capability. Although the bacterium is believed to be highly tolerant to the harmful effect of this herbicide, a concentration of $800 \mathrm{mg} / \mathrm{L}$ was found to be very toxic to the current microorganism and therefore inhibits its growth, the growth curve showed a steep fall signifying a steady decline phase. This finding goes somewhat in line with the findings of another study that used Pseudomonas putida $\mathrm{G} 3$ to biodegrade butachlor, the bacteria was found to survive up to $1000 \mathrm{mg} / \mathrm{L}$ concentration [18] thus more tolerant than the present bacterium. The high tolerance exerted by this strain is probably due to its ability to utilize the chemical more effectively and have better enzymes that can easily degrade it into simpler metabolites that can be consumed compared to the strain used in this study.

Another experiment set to determine the optimum inoculum size revealed that after $24 \mathrm{~h}$ of incubation, the organism showed the highest growth with $1000 \mu \mathrm{L}$ of the inoculum compared to all to any other tested volume, this can be explained looking at the fact that the bacterium has no lag phase as none is observed in any case, adaptation was therefore fast and so was achieving exponential phase. The nature of the growth curve also showed that the growth rate of the bacterium increases with increasing volume of inoculum after $24 \mathrm{~h}$ incubation period. Similar findings were reported by $[18,19]$ that highest growth and degradation of butachlor is achieved at high inoculum volume.

In the present study, $\mathrm{pH}$ of $5.5-8.0$ range was also tested. $\mathrm{pH}$ being an important physical parameter affecting the growth of microorganisms in any environment by influencing its metabolic processes while also affecting the transport of molecules in and out of the cell, almost any microbe has a certain range of $\mathrm{pH}$ in which it grows and conduct its activities best. This study showed that the isolate grows best at a $\mathrm{pH}$ range between $6.0-6.5$ when exposed to this pollutant signifying the strong possibility of the strain being acidophile in nature. Other studies conducted using different other microorganisms showed different optimal $\mathrm{pH}$ range, of which Pseudomonas alcaligens, Bradyrhizobium sp. Bacillus megaterium, with $\mathrm{pH} 5.0$ as optimal, a $\mathrm{pH}$ that is more acidic than the optimum of the strain used in this study and also Catellibacterium caeni sp. nov DCA$1 \mathrm{~T}$ with optimal $\mathrm{pH}$ between $6.0-9.0[20,21]$.

Finally, test aimed at determining the optimum temperature that supports the best growth of this bacteria was also carried out within a range of $25-45{ }^{\circ} \mathrm{C}$, of the various set temperature values, the optimum temperature for this Pseudomonas sp. to degrade butachlor was found to be between $30-37^{\circ} \mathrm{C}$ after $24 \mathrm{~h}$ incubation. This correspond to the findings of [16] in a study aim at using Bacillus altitudinis to biodegrade butachlor, the optimum temperature was also found to be $37^{\circ} \mathrm{C}$. An optimum temperature of $35{ }^{\circ} \mathrm{C}$ was also reported in the butachlor biodegradation of three bacteria (Pseudomonas alcaligens, Bradyrhizobium sp. Bacillus megaterium) [20], a value that lies within the optimum range of this study. Since temperature has a great impact on the metabolic processes occurring in the organism as it affects the rate of enzyme activity and deviation from the optimum temperature may lead to the loss of activity of enzymes as a result of denaturation or inactivation, this temperature is therefore necessary to insure the best tolerance and activity of the bacterium for effective bioremediation.

\section{CONCLUSION}

The Pseudomonas sp. used in this study was found to best degrade butachlor at $\mathrm{pH}$ between 6.0 and 6.5 , temperature between $30-37^{\circ} \mathrm{C}$ and can tolerate the pollutant up to $600 \mathrm{mg} / \mathrm{L}$ concentration with continuous increase in growth as inoculum size increases. Additionally, this study also revealed that the bacterium has no lag phase regardless of the concentration of the butachlor used. Furthermore, $24 \mathrm{~h}$ of incubation was found to be the time period over which the bacterium achieves its maximum growth.

\section{REFERENCES}

1. Fishel F, Ferrell J, Macdonald G, Sellers B. Herbicides: How Toxic Are They? 2016;1-2.

2. Jaiswal A, Kumar A, Mishra S. Detection of Butachlor in Viscera by Thin Layer Chromatography. J Indian Soc Toxicol. 2011;7(1):38-40

3. Kim NH, Kim DU, Kim I, Ka JO. Syntrophic biodegradation of butachlor by Mycobacterium sp. J7A and Sphingobium sp. J7B isolated from rice paddy soil. FEMS Microbiol Lett. 2013;344(2):114-20.

4. Abigail MEA, Samuel SM, Ramalingam C. Addressing the environmental impacts of butachlor and the available remediation strategies: a systematic review. Int $\mathrm{J}$ Environ Sci Technol. 2015;12(12):4025-36.

5. Panneerselvam N, Sinha S, Shanmugam G. Butachlor is cytotoxic and clastogenic and induces apoptosis in mammalian cells. Indian J Exp Biol. 1999;37(9):888-92.

6. Dwivedi S, Saquib Q, Al-Khedhairy AA, Musarrat J. Butachlor induced dissipation of mitochondrial membrane potential, oxidative DNA damage and necrosis in human peripheral blood mononuclear cells. Toxicology. 2012 Dec 8;302(1):77-87.

7. Tilak KS, Veeraiah K, Thathaji PB, Butchiram MS. Toxicity studies of butachlor to the freshwater fish Channa punctata (Bloch). J Environ Biol. 2007; 28(2 SUPPL.):485-7.

8. Gobi M, Gunasekaran P. Effect of Butachlor Herbicide on Earthworm Eisenia fetida - Its Histological Perspicuity. Appl Environ Soil Sci. 2010; 2010: 1-4.

9. Muthukaruppan G, Janardhanan S, Vijayalakshmi G. Sublethal Toxicity of the Herbicide Butachlor on the Earthworm Perionyx sansibaricus and its Histological Changes ( $5 \mathrm{pp})$. J Soils Sediments [Internet]. 2004;5(2):82-6. Available from: https://doi.org/10.1065/jss2004.09.111

10. Mohanty SR, Nayak DR, Babu YJ, Adhya TK. Butachlor inhibits production and oxidation of methane in tropical rice soils under flooded condition. Microbiol Res. 2004;159(3):193-201.

11. Boyd SA, Shelton DR, Berry D, Tiedje JM. Anaerobic Biodegradation of Phenolic Compounds in Digested Sludget. 1983;46(1):50-4.

12. Abatenh E, Gizaw B, Tsegaya Z, Wassie M. Application of microorganisms in bioremediation-review. J Environ Microbiol. 2017;1(1):2-9.

13. Verma JP, Jaiswal DK. Book Review: Advances in Biodegradation and Bioremediation of Industrial Waste. Front Microbiol. 2016;6(January):2.

14. Khan SA, Hamayun M, Khan AL, Ahmad B, Lee I. Influence of $\mathrm{pH}$, temperature and glucose on biodegradation of 4-aminophenol by a novel bacterial. 2009; 8(16): 3827-31.

15. Azubuike CC, Chikere CB, Okpokwasili GC. Bioremediation techniques-classification based on site of application: principles, advantages, limitations and prospects. World J Microbiol Biotechnol. 2016;32(11).

16. Kaur R, Goyal D. Biodegradation of Butachlor by Bacillus altitudinis and Identification of Metabolites. Curr Microbiol [Internet]. 2020;(0123456789). Available from: https://doi.org/10.1007/s00284-020-02031-1

17. Duc HD, Thi N, Thuy D, Thi H, Truc T, Nhu TH, et al. Degradation of butachlor and propanil by Pseudomonas sp. strain But 2 and Acinetobacter baumannii strain DT. 2020;(June):1-8. 
18. Mohanty SS, Jena HM. Degradation kinetics and mechanistic study on herbicide bioremediation using hyper butachlor-tolerant Pseudomonas putida G3. Process Saf Environ Prot [Internet]. 2019;
125:
$172-81$
Available
from:

https://doi.org/10.1016/j.psep.2019.03.014

19. Jena HM, Mohanty SS. Evaluation of butachlor biodegradation efficacy of Serratia ureilytica strain AS1: a statistical optimization approach. Int J Environ Sci Technol [Internet]. 2018;(0123456789). Available from: https://doi.org/10.1007/s13762-018-1958-6

20. Sherif HAA, Mounir MSB. Microbial biodegradation of butachlor pollution (obsolete pesticide Machete 60\% EC). African J Microbiol Res. 2013;7(4):330-5.

21. Zheng J, Li R, Zhu J, Zhang J, He J, Li S, et al. Degradation of the chloroacetamide herbicide butachlor by Catellibacterium caeni $\mathrm{sp}$. nov DCA-1T. Int Biodeterior Biodegradation [Internet]. 2012 Sep 1 [cited 2020 Mar 8]; 73: 16-22. Available from: https://www.sciencedirect.com

/science/article/pii/S0964830512001369. 